\title{
Gene-editable materials for future transportation infrastructure: a review for polyurethane-based pavement
}

\author{
Bin Hong ${ }^{1}$, Guoyang Lu² ${ }^{2^{*}}$, Tianshuai Li ${ }^{1}$, Jiao Lin ${ }^{1}$, Dawei Wang ${ }^{1,3^{*}}$, Dong Liang ${ }^{4}$ and Markus Oeser ${ }^{3}$
}

\begin{abstract}
With the rapid development of society and industry, novel technologies and materials related to pavement engineering are constantly emerging. However, with the continuous improvement of people's demands, pavement engineering also faces more and more enormous challenges that the pavement materials must have excellent engineering properties and environmental benefits. Meanwhile, the intelligence is the mainstream development direction of modern society, and the development trend of future transportation infrastructure. Materials Genome Initiative, a program for the development of new materials that materials design is conducted by up-front simulations and predictions, followed by key validation experiments, the rapid development of science and technology and Al toolset (big data and machine learning) provide new opportunities and strong technical supports for pavement materials development that shorten the development-application cycle of new material, reduce cost and promote the application of new carriers such as intelligent sensing components in transportation engineering, to achieve the intelligence of transportation engineering. However, traditional pavement materials possess several unavoidable shortcomings, indicating that it is exceedingly difficult for them to meet the above requirements for future pavement materials. Therefore, the development of future new pavement materials, which can be designed on-demand as well as possessing enough mechanical properties, high durability, practical functionality, and high environmental protection, is urgent. In recent years, as a "designable" polymer material with various excellent engineering performances, polyurethane (PU) has been widely applied in pavement practices by changing the chemical structures of raw materials and their mix proportions, for instance pavement repairing material, permeable pavement material, tunnel paving material and bridge deck paving materials, etc. Although PU material has been widely applied in practices, a systematically summarization is still quite necessary for further understanding the working mechanism of PU materials and optimization it's engineering applications. To fill the gap, this article puts forward the special requirements for future transportation infrastructure materials, and introduces the basic properties and working mechanism of PU materials in order to make up for the defects of conventional road materials. Based on this, this article also summarizes the engineering performances and environmental benefits of applying PU as the binder for different road infrastructure materials in recent years. Considering the gene-editable nature of polyurethane, further research of the on-demand design principles of PU pavement materials is recommended. The establishment of raw material gene database, material terminal
\end{abstract}

\footnotetext{
*Correspondence: guoyang.lu@polyu.edu.hk; wang@isac.rwth-aachen.de

1 School of Transportation Science and Engineering, Harbin Institute

of Technology, 73 Huanghe Road, Nangang District, Harbin 150090, P.R

China

${ }^{2}$ Department of Civil and Environmental Engineering, The Hong Kong

Polytechnic University, 11 Yuk Choi Road, Hung Hom, Kowloon, Hong

Kong, P.R. China

Full list of author information is available at the end of the article
}

(C) The Author(s) 2021. Open Access This article is licensed under a Creative Commons Attribution 4.0 International License, which permits use, sharing, adaptation, distribution and reproduction in any medium or format, as long as you give appropriate credit to the original author(s) and the source, provide a link to the Creative Commons licence, and indicate if changes were made. The images or other third party material in this article are included in the article's Creative Commons licence, unless indicated otherwise in a credit line to the material. If material is not included in the article's Creative Commons licence and your intended use is not permitted by statutory regulation or exceeds the permitted use, you will need to obtain permission directly from the copyright holder. To view a copy of this licence, visit http://creativecommons.org/licenses/by/4.0/. 
performance database and their structure-activity relationship are highlighted. The current research is essential to the practice guidance and further optimization of the PU materials for road infrastructures, which in line with the future Carbon neutral policy.

Keywords: Polyurethane, Green House Gas (GHG), Gene-editable Materials, Future Pavement materials, Carbon Neutral

\section{Introduction}

To ensure that the highways and urban roads meet the requirements of vehicle operation to the maximum extent, maintain the designed speed, enhance safety and comfort, reduce transportation costs and extend the road service life, the pavement should have the following series of basic performance [1]: 1) Adequate structural load-bearing capacity; 2) Sufficient structural stability under a series of severe conditions, such as rainfall high temperature, low temperature, freeze-thawing, etc.; 3) Adequate durability under the above severe conditions and even vehicle loads; 4) Good surface smoothness; 5) Good road skid resistance.

With the rapid development of society and industry, novel technologies and materials related to pavement engineering are constantly emerging. Asphalt, concrete, and novel polymer materials play dominant roles in the field of pavement materials.

\section{Asphalt pavement materials}

Asphalt binder is a kind of organic cementitious material with complex composition, which can be divided into artificial asphalt and natural asphalt [2]. Artificial asphalt also can be divided into tar asphalt and petroleum asphalt, which are the by-products of coal tar refining and petroleum distillation, respectively [2].

Asphalt material occupies an especially important position in pavement engineering. In recent decades, most flexible pavements have used asphalt binder as the basic paving material $[3,4]$. As a road paving material, asphalt has a high binding force and can provide sufficient surface properties, such as flatness, sufficient roughness, rolling resistance, and macrotexture [2]. These surface characteristics make the pavement have sufficient friction, help improve skid resistance to ensure driving safety and driving comfort, and reduce noise levels [5-8].

However, ordinary asphalt mixture pavement has some performance defects, such as non-prominent high and low-temperature performance and poor aging resistance. For coping with the requirements of pavement materials caused by the rapid increase of traffic load and variable environmental factors, various modifiers, including polymers (Styrene-Butadiene-Styrene (SBS), PE, EVA, SBR, PET, etc.) [9-12], crumb rubber (CR) [13, 14], nanomaterials, etc., were achieving continuous attention and widely used in the field of asphalt modification. At the same time, functional asphalt mixtures, including the self-cleaning pavement, de-icing pavement, selfpowered pavement, and permeable pavement, have been rapidly developed. Meanwhile, the potential of applying advanced materials to asphalt pavement has been gradually developed, such as self-healing materials, polyurethane, polyphosphoric acid, basalt fibers, carbon fibers, etc.

In recent years, fuel consumption, greenhouse gas emissions and VOCs pollution during asphalt mixing have received increasing attention from society [15-18]. Asphalt binder is a non-renewable energy source, so asphalt becomes an environmentally unfriendly material [19]. In addition, due to the global shortage of energy in recent years, the cost of fossil fuels has increased dramatically, and the cost of asphalt has also increased. Therefore, the continued use of traditional asphalt materials will not be compatible with the concepts and principles of sustainability in the future. The use of environmentally friendly materials instead of asphalt materials can not only contribute to the sustainable environment but also improve the economy $[9,20,21]$.

In fact, there are limited ecological alternatives that can completely replace asphalt materials. In terms of the innovative asphalt mixture technology, there are already many innovative options to reduce the use of bitumen, although some of the alternative materials require the modification of mixture design, and the cost of modification may be high, such as the application of polymer materials. However, the environmental pollution caused by asphalt production has been reduced by using these innovative methods, and the durability of road materials has also been greatly enhanced [22, 23].

\section{Conventional cementitious pavement materials}

Cement is made up of limestone, clay, iron ore by calcining at high temperature and mixed with gypsum. Cement concrete pavement is characterized by significant mechanical advantages (strength, durability, fatigue resistance, etc.), low cost, noninflammability, etc., [24]. These excellent properties make cement has been mainly used in rural road pavements, heavy-duty traffic road pavements, airports and tunnels. Cement is mainly used for paving concrete roads, and colleagues can also be 
used as stabilizers for the base layer and the bottom layer $[25,26]$.

In recent years, great progress has been made in the design theory, material and construction technology, detection and maintenance technology in the field of cement pavement construction. However, the development and application of cement concrete pavement still are prevented due to its poor anti-skid and noise reduction performance, difficult maintenance and large temperature stress, which has always been the focus in cement concrete pavement research. Besides, there is a lot of engineering practice and research on the asphalt overlay on old cement concrete pavement [27, 28]. The rapid non-destructive testing of the service condition and structural diseases of cement concrete pavement has been paid attention to by road workers all over the world [29]. Concerning the pavement forms, the continuous reinforced concrete pavement (CRCP) got wide attention $[30,31]$. Moreover, the prefabricated assembly technology based on cement materials has been developed and received more attentions.

However, the negative impact of cement production on the environment and economy cannot be ignored. Cement production accounts for about $8 \%$ of global greenhouse gas emissions [32]. About half of these emissions are related to industrial cement production, while the other half are related to fuel combustion during the entire process [33]. This percentage value does not seem to be mathematically significant, but the total amount of this percentage is not ignored or underestimated on a global scale. Therefore, reducing cement consumption and productivity will promote sustainable development, benefit the environment, economy, and indirectly benefit society [34]. To alleviate these negative effects, it is necessary to develop new environmentally friendly materials that can replace traditional cement pavements [35].

\section{Requirements for future pavement materials}

With the continuous improvement of people's demands, pavement engineering also faces more and more enormous challenges that the pavement materials must have excellent properties, including high- and low-temperature performance, toughness, rutting resistance, long life cycle, etc., to meet the pavement requirements due to the rapid growth of traffic volumes and loads, and worsening extreme environment. Meanwhile, environmental friendliness is the unswerving development direction of road materials for both resource-saving and environmental protection. As mentioned above, the traditional pavement materials possess several unavoidable shortcomings, indicating that it is very difficult for them to meet the above requirements for future pavement materials. Especially, for the most commonly used asphalt pavement material, the specific chemical composition of bitumen is still unknown which cannot achieve the requirements of design on demand. Therefore, the development of future new pavement materials, which can be designed on-demand as well as possessing enough mechanical properties, high durability, practical functionality and high environmental protection, is urgent.

Moreover, intelligence is the mainstream development direction of modern society, and the development trend of future transportation engineering. Materials Genome Initiative, showing in Fig. 1 [36], a program for the development of new materials that materials design is conducted by up-front simulations and predictions, followed by key validation experiments [37], the rapid development of science and technology and AI toolset (big data and machine learning) provide new opportunities and strong technical supports for pavement materials development that shorten the development-application cycle of new material, reduce cost and promote the application of new carriers such as intelligent sensing components in transportation engineering, to achieve the intelligence of transportation engineering [38].

\section{Novel polyurethane pavement material}

In view of the above requirements for future pavement materials, a novel polyurethane (PU)-based pavement material was proposed and applied to heavy duty pavement by RWTH Aachen University and BASF GmbH since 2010 and is considered as one of the most likely materials to replace the conventional asphalt pavement materials. Due to PU binder exhibits high mechanical

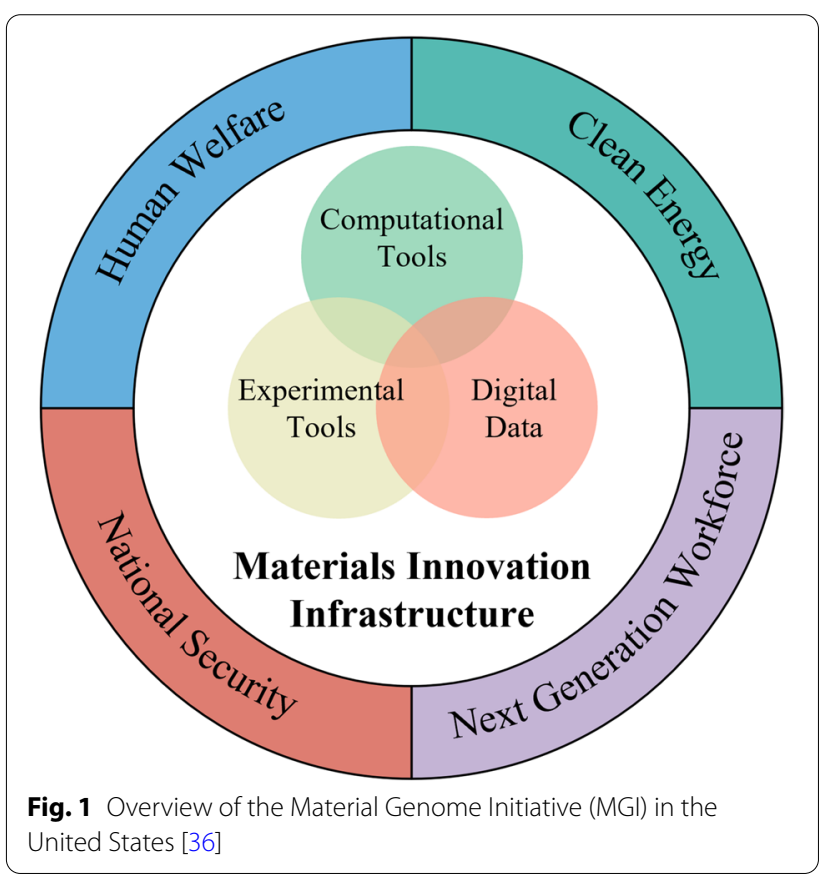


property $[39,40]$, good chemical durability $[41,42]$, high elasticity [43], designable performance [44], low energy [39], environmental conservation [39], etc., PU binder was further applied in porous pavement to overcome the challenges of conventional porous asphalt mixtures since 2014 [45, 46]. The novel PU bound pervious mixtures provide a favorable combination of functionality and mechanical properties [20, 47, 48], and it was further applied for full-scall pavement test and actual construction for pavement infrastructures since 2018 [22, 49, 50]. Recent years, a high resistance to deformation and fatigue of PU pavement materials were also proven based on laboratory research, in which case PU binder was further studied as ultra-thin layer for tunnel pavement [39, 51] and bridge deck pavement [52-54].

Similar to the conventional asphalt pavement material, the polyurethane pavement material is composed of a certain amount of polyurethane binder and a certain gradation of aggregates. However, contrary to the conventional asphalt pavement material, the polyurethane pavement material is mixed and cured at ambient temperature [39]. In contrast to the asphalt pavement material, it is worth noting that although the polyurethane pavement material has many above mentioned advantages, its disadvantages mainly include three points: 1) a bit higher brittleness, however, its low-temperature performance is still meet the requirement of the standard; 2) poor water stability, however, its residual performance is still much higher than the former [39]; 3) high cost, for example, for the two-way and 3-lane highway with thickness of $0.04 \mathrm{~m}$ and width of 3.75 for each lane, the cost of the base asphalt pavement material is about 517,000 yuan while the cost of the polyurethane pavement material is about $1,757,700$ yuan, which is mainly because polyurethane is almost 10 times more expensive than base bitumen. Therefore, the polyurethane pavement material is primarily considered for use in road surface layer that do not care about cost, such as bridge deck pavement, airfield pavement and tunnel pavement. Fortunately, the polyurethane pavement material has been proved to have a long serice performance, for example, 8 times the fatigue life of Asphalt mace aggregate (SMA) mixture [53]. In addition, the polyurethane pavement material is not only used as a repair pavement [55], but also as an overlay or a new pavement layer.

\section{Polyurethane materials}

Polyurethane (PU) discovered by Otto. Bayer in 1937 [44, $56]$ is a general name for a polymer whose backbone contains a repeating carbamate group $(-\mathrm{NHCOO}-)$ which forms from the addition polymerization between organic diisocyanates or polyisocyanates and dihydroxy or polyhydroxy compounds (polyols) [56].

\section{Overview}

The reaction mechanism of PU is shown in Eq. (1) [39]. As shown, the molecular structure of PU is classified into hard segments and soft segments which provide the strength and toughness of PU [44], respectively. PU material is a multipurpose synthetic resin with various forms, which has been applied to transportation, architecture, mechanical engineering, electron industry, furniture, food processing, textile industry, metallurgic industry, chemical industry, hydraulic engineering, sports, medical industry, etc., [56].

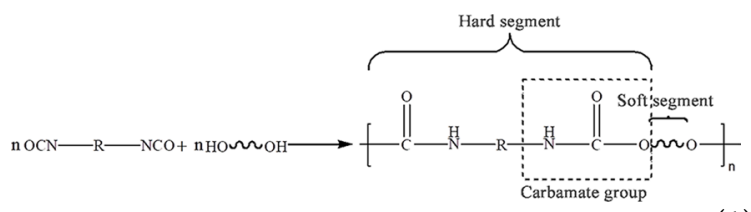

\section{Genetic characteristics of PU materials}

PU is a "designable" polymer material between plastic and rubber, which can produce products with various performance by changing the chemical structures of raw materials and their mix proportion. Therefore, the PU materials can be designed as needed in accordance with the Materials Genome Initiative (MGI), showing in Fig. 1, proposed by the United States [36].

The genetic characteristics of PU are mainly classified into raw material composition, geometric structure, void structure and forming process parameters. The raw materials of PU consist of isocyanates, polyols and additives, among which the auxiliaries consist of catalysts, solvents, plasticizers, chain extenders, crosslinking agents, durability additives, fillers, flame retardant, colorant and other additives. Each material genome for PU corresponds to performance. Therefore, there are tens of millions of variations in PU due to the selection of different genetic characteristics. According to the design idea of the material genome, the material genome design for PU consists of three steps: 1) create a material genome database; 2) establish the corresponding relation between the material genome and the macro performance of PU based on the high throughput characterization and a small number of tests; 3 ) determine the genomic characteristic parameters of $\mathrm{PU}$ according to the needs.

Up to now, the PU mixtures have been successfully applied to kinds of light-load pavements, such as park roads, sidewalks, sports grounds, runways, etc. In recent years, PU has gradually been considered as a binder for pavement materials [57] due to its some excellent properties, such as high adhesive property with aggregates, high 
elasticity, chemical corrosion resistance, light resistance, abrasion resistance, strong shock absorption, tear resistance, designable hardness and softness.

For the polyurethane binder, the thermo-mechanical properties, rheological property, and durability including corrosion resistance and $\mathrm{UV}$ aging resistance are the crucial evaluation index for pavement materials. B. Hong et al. [42] has given the investigation in thermo-mechanical properties, rheological property and their durability under UV aging. The results showed that the PU binder used has excellent anti-ultraviolet aging ability as well as good thermo-mechanical properties and rheological property, and the anti-aging ability can be improved to a certain extent with the appropriate increase of isocyanate content. In addition, the PU binder also possesses excellent corrosion resistance in water, seawater and even alkaline solution immersion $[41,58,59]$.

\section{Design of the PU binder as pavement material}

Like the definition of asphalt mixtures, polyurethane mixtures (PUMs) are those formed by mixing a certain grade of mineral materials and a certain proportion of roadused polyurethane binder at outdoor ambient temperature. It is noted that the polyurethane mixture (PUM) is also inevitably subjected to the combined effects between some severe environments and vehicle loads. The above severe environments mainly include high temperature, low temperature, rainfall, freeze thawing, ultraviolet irradiation, etc. Therefore, it is necessary to design the polyurethane pavement material according to its requirements.

The PUM consists of aggregates, voids and PU binder, respectively, seeing in Fig. 2.

As shown in Fig. 1, the basic three elements of MGI are computational tools, experimental tools and digital data, respectively. The computational tools are mainly to establish an accurate prediction model of the performance of the material, which can be modified by relevant theories and empirical data. The experimental tools are mainly to:
1) make connections between computations at different scales; 2) supplement some basic data, including physical, chemical, electronic, mechanical, optical and other properties, which serves to build the internal relations between the composition, organization and forming process, and further establish a large database; 3 ) modify the above theoretical calculation prediction model by using experimental data, and accelerate the screening and efficient determination of new materials. The Digital data are mainly related to the establishment, standardization and sharing of digital data of different materials. According to the above description, similar to the asphalt mixture [60], the genetic characteristics of PUM include the material characteristic gene, meso-structural characteristic gene, microstructural characteristic gene and preparation process characteristic gene. According to the MGI [36], PUM can be designed according to its requirements, seeing in Fig. 3.

The material characteristic gene consists of the material composition and proportion of polyurethane binder, the mineral composition, size and morphology of aggregates, and the gradation of PUM. Aggregate is an important part of asphalt mixture, accounting for about $95 \%$ of the total mass of asphalt mixture, whose chemical composition and mechanical characteristics directly affect the mechanical properties of the asphalt mixture. According to mineral lithology, aggregate can be divided into basalt, limestone, granite, sandstone, etc. According to the material source, aggregate can be divided into gravel, pebble, natural gravel, etc. According to the particle size, aggregate can be divided into coarse aggregate, fine aggregate, and ore powder [60].

The meso-structural characteristic gene consists of the mesoscopic void distribution and mesoscopic aggregate distribution. The microstructural characteristic gene mainly refers to the interfacial structure between the polyurethane binder and aggregates. The preparation

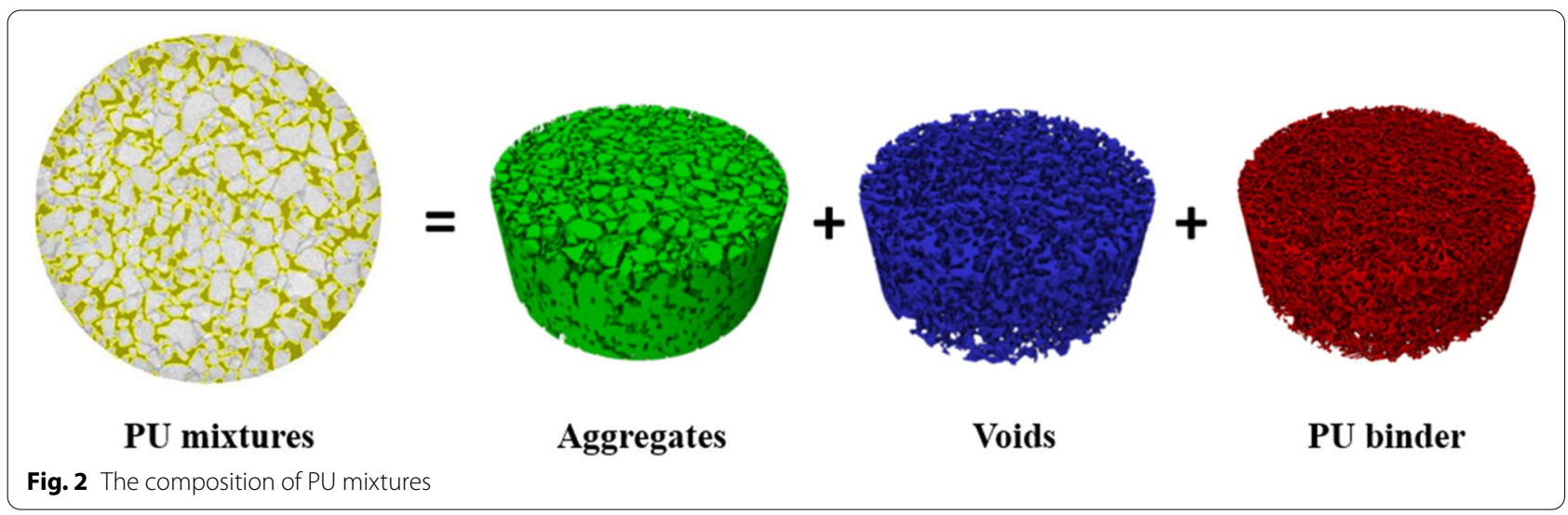




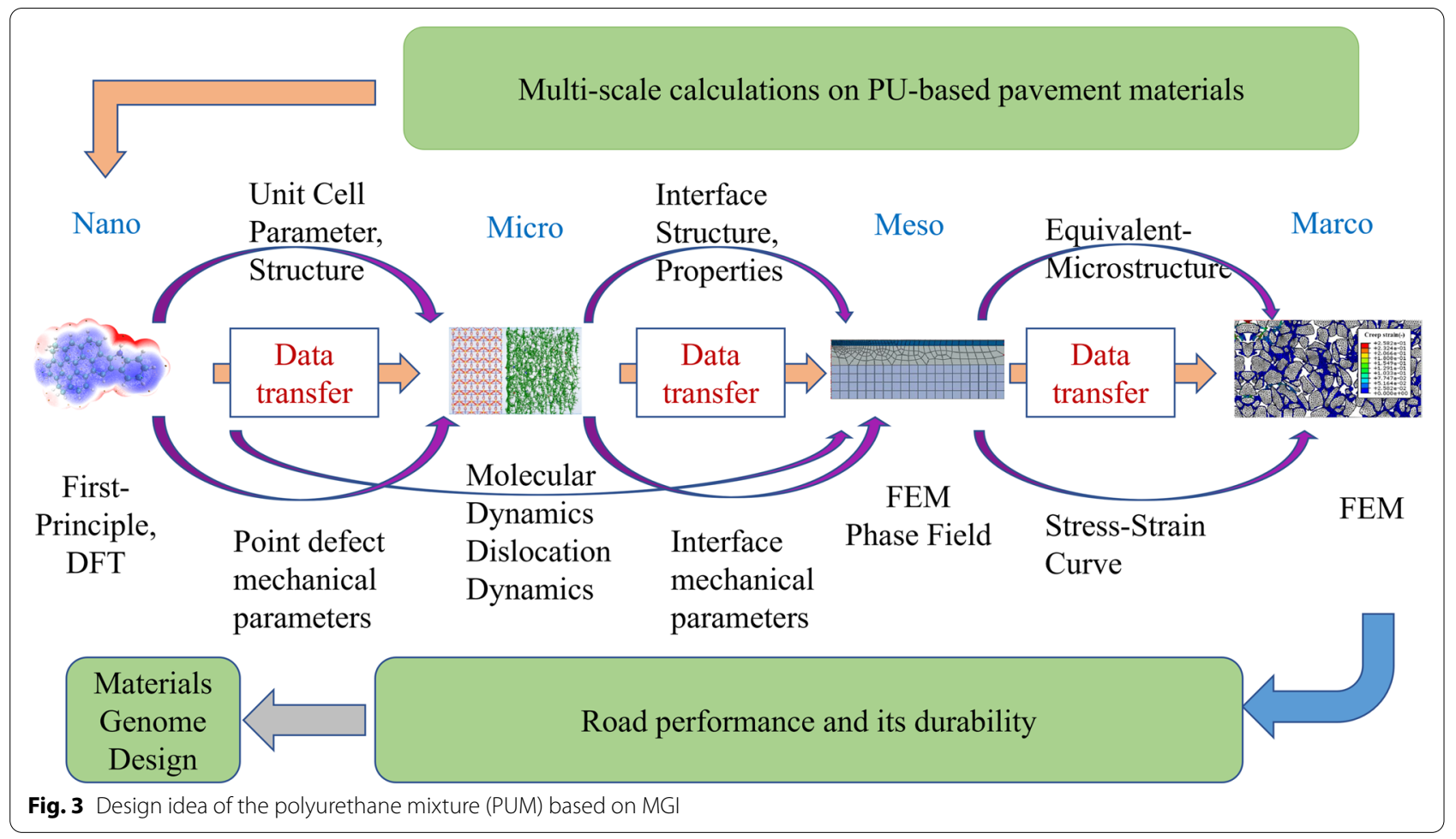

process characteristic gene is related to various process parameters.

\section{Application of PU as the binder for road infrastructure}

As is well-known, the conventional asphalt binder is a complex black-brown mixture that consists of hydrocarbons with different molecular weights and their nonmetallic derivatives. The asphalt binder is a high viscosity organic liquid that is often in the form of liquid or semisolid petroleum. However, the cured PU binder is a polymer in the form of solid plastic, rubber or elastomer, whose road performance cannot be characterized like the asphalt binder.

As mentioned above, PU has a lot of excellent properties when it is considered as a binder for pavement materials. Besides the benefits mentioned above, another environmental benefit is found in potential energy savings and the reduction in greenhouse gas (GHG) emissions by using PU binder [39]. During conventional asphalt mixture production, temperatures of the aggregate and the bitumen must be raised sufficiently high to facilitate the coating of aggregate with bitumen. This temperature has to be maintained during construction to ensure the workability of the asphalt. As a result, conventional asphalt production is an energy intensive process. The PU pavement materials, however, can be produced and constructed at room temperature and only a common compactor is requested during construction.

\section{Polyurethane repair material}

As mentioned above, the two most conventional paving materials, cement concrete and asphalt mixture, are inevitably damaged in service. As an excellent representative of novel polymer material, when the polyurethane is designed as rigid form, it has the characteristics of lightweight, high specific strength, strong adhesion to other substances, rapid curing at room temperature and excellent durability [61-63]. It is an excellent structural material and was firstly developed as a pavement repair material in 1990s [64, 65].

In recent years, polyurethane is often used for the rapid repair of important roads, such as i) highway pavement: In the service life cycle of asphalt pavement, due to the coupling effect of environmental factors and traffic load, aging and cracking often occur on asphalt pavement [66]. If it is not maintained or repaired in time, water will enter the cracks, which will accelerate the water damage of the pavement materials and affect the adhesion between the upper and lower layers of the asphalt pavement [67]. In addition, under the action of vehicles, potholes will appear on the road, which will eventually hinder the traffic on the road. Polyurethane is often used in the preventive maintenance of asphalt pavement and pothole repair. On the one hand, polyurethane has the characteristics 
of high strength, water resistance, and aging resistance. Researchers proposed to use polyurethane materials to modify emulsified asphalt to meet the maintenance requirements of asphalt pavements $[68,69]$. On the other hand, polyurethane is used to manufacture the memory material of asphalt pavement to solve the problems of existing asphalt materials that are difficult to adapt to temperature deformation, UV aging, elastic recovery and poor mechanical properties [70]; ii) airport cement pavement concrete: The conventional repair materials and techniques cannot meet the strict requirement of airport pavement in quality and time of repair. Due to the novel polyurethane repair materials being equipped with excellent mechanical properties and low shrinkage deformation, these were proved to be suitable for use as a repair material for airport pavement of asphalt and cement [71]. Furthermore, Huang et al. investigated the fabrication and improvement of the polyurethane (PU)-based polymer concrete (PC) for rapid cementitious runway repair [55]; and iii) tunnel paving: As a closed space, the functional requirements of the tunnel pavement are distinct from the ordinary pavement. In recent years, with the increasing requirements for the safety, comfort and environmental friendliness of tunnel pavement, asphalt pavement has been questioned for using as pavement materials in the tunnel in terms of meeting the goal of sustainability and environment friendly. Because polyurethane to pavement does not need to be heated during paving and forming strength, it emits less greenhouse gas, which is very suitable for paving and rapid repair of tunnel pavement. Innovative thin polyurethane overlay
(PTO) has been developed to maintain existing roads and construct new ones [51].

\section{Polyurethane permeable pavement material}

Compared to conventional pavement structures, porous pavements are not only designed to bear traffic loads but also play an important role in noise reduction and water management [72-74]. To achieve a high permeability, a void-rich pavement structure such as PA and PC with open-graded aggregate are currently the most feasible and effective approach to ensure sufficiently high void contents. However, the open porous design results in a significantly weakened pavement structure as stated before; adhesion failure and the limited durability of porous pavement mixtures has been the most prominent obstacle, limiting the widespread application of permeable pavements [74-83].

PU binder is exhibiting a high mechanical and chemical durability to overcome the challenges of conventional porous asphalt mixtures [46, 47, 49, 84, 85]. The excellent performance of $\mathrm{PU}$ indicates that the material provides a favourable combination of functionality and mechanical properties $[22,50,86]$. A comparison of the mechanical properties between PUPM and conventional porous pavement materials can be shown in Table 1. High resistance to deformation and fatigue of PUPM pavements are proven in previous research. During the reaction process, the two liquid components cure and become solid polyurethane, thereby proving the mechanical strength between the aggregates. The manufacturing process of PUPM is illustrated in Fig. 4.

Table 1 Mechanical properties between PUPM and conventional porous pavement materials

\begin{tabular}{llll}
\hline Type of mixture & Compressive strength (MPa) & Tensile strength (MPa) & Young's modulus (GPa) \\
\hline PUPM [47] & $18.63 \pm 1.39$ & $3.36 \pm 0.38$ & $6.64 \pm 0.08$ \\
PA [87] & $2.00 \pm 0.25$ & $0.75 \pm 0.25$ & $0.40 \pm 0.10$ \\
PC [88] & $19.00 \pm 2.50$ & $1.69 \pm 0.25$ & $20.00 \pm 0.73$ \\
\hline
\end{tabular}
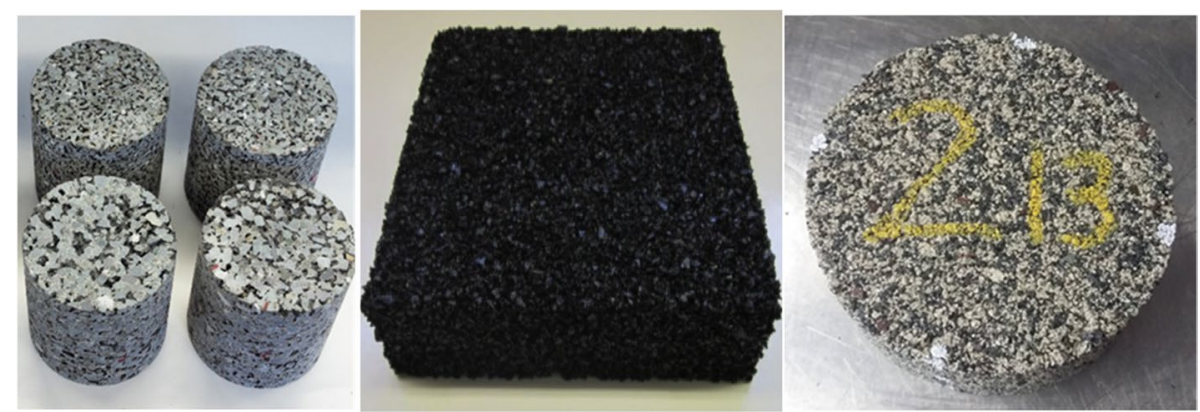

Fig. 4 Samples of PUPM [50] 
Based on the excellent properties of the PU binder, several functional and sustainable pavement materials have been developed. Among those materials, the most widely known is Poroelastic Road Surface (PERS). PERS is a novel type of pavement surface, which includes recycled tire rubber into low-noise pavements as aggregate [43]. Based on the PU binder applied in the previous research, the tensile strength was improved significantly in cold temperature $[89,90]$. The sound absorption coefficients of PERS have higher and wider peaks compared with conventional PA. It proved the suitability of PERS for urban roads in cold regions and outlined the significant economic and social benefits.

Another sustainable application is to develop a new pervious pavement material by replacing natural aggregate with recycled ceramic aggregate and replacing bitumen with a PU binder, so-called PU-bound Ceramics Recycled (Porous) Pavement (PCRP) material [22]. The PCRP material exhibits high compressive strength and low permanent deformation. The high proportion of ceramic aggregate and the strong cohesive strength of PU result in a large elastic modulus. An extremely high hydraulic conductivity was achieved with a high void content and improved void connectivity. Thus, PCRP is suitable to be widely adopted for the construction of permeable pavement systems for improving stormwater drainage. Furthermore, PCRP shows superior acoustic properties in comparison with conventional PA 8.

In contrast to conventional hot-mix asphalt, PCRP production does not need any heating and therefore results in a significant reduction in energy use and greenhouse gas emissions. PCRP uses environmentally friendly raw materials, and the whole production process is "cleaner" compared to that of conventional asphalt mixtures. With potential environmental and economic benefits, further studies are needed to investigate the fatigue behavior and durability of the material and optimize the material design.

The difference in energy use and GHG emission for producing and placing the two materials was analyzed in detail.

As discussed above, the differences in energy use and GHG emissions between PA and PU pavement materials are mainly attributed to different mixture production and construction conditions. Based on the previous research, producing one ton of the PU mixture only requires $0.16 \mathrm{KWh}$, equivalent to $0.58 \mathrm{MJ}$. The energy consumptions and GHG emissions in terms of $\mathrm{CO}_{2}$-equivalent $\left(\mathrm{CO}_{2}\right.$-e $)$ for one tone of the respective mixtures are shown in Table 2. PU pavement material consumes much less energy and generates less GHG emissions since it does not need to be heated for mixing and pavement manufacturing.

In a special situation, the construction of one lanekilometer of pavement (thickness is assumed to be 40 $\mathrm{mm}$ and the lane width is assumed to be $3.8 \mathrm{~m}$ ), the production and construction of PU pavement requires much less energy and generates much less GHG emissions (less than 10 percent in comparison to conventional porous asphalt pavements). However, the price estimate suggests that the use of PU mixture is still an expensive choice mainly due to the price of PU (PU binder currently is about 5 times more expensive than polymer-modified bitumen). However, due to the excellent durability and functionality of noise absorption and stormwater management, the monetary value of PU materials should still be considered in the future.

\section{Polyurethane tunnel pavement material}

The increase of requirements for pavements in tunnels including safety, comfort and environmental

Table 2 Energy consumptions and GHG emissions in producing one ton of mixtures [22]

\begin{tabular}{|c|c|c|c|c|c|c|c|c|}
\hline \multirow[t]{2}{*}{ Material } & \multicolumn{2}{|c|}{ Fuel consumption } & \multicolumn{3}{|c|}{ Energy consumption (MJ) } & \multicolumn{3}{|c|}{$\mathrm{GHG}\left(\mathrm{CO}_{2}-\mathrm{e}\right)(\mathrm{kg})$} \\
\hline & Type & Rate & Fuel & Electricity & Total & Fuel & Electricity $^{a}$ & Total \\
\hline \multirow[t]{3}{*}{ Diabase + bitumen } & Diesel (kg) & 5.74 & 191.07 & 5.21 & 196.28 & 15.02 & 4.56 & 19.58 \\
\hline & Heavy oil (kg) & 5.66 & 191.07 & 5.21 & 196.28 & 18.17 & 4.56 & 22.74 \\
\hline & Natural gas $\left(\mathrm{m}^{3}\right)$ & 6.97 & 191.07 & 5.21 & 196.28 & 13.41 & 4.56 & 17.97 \\
\hline \multirow[t]{3}{*}{ Granite + bitumen } & Diesel $(\mathrm{kg})$ & 7.54 & 271.29 & 5.21 & 276.50 & 19.73 & 4.56 & 24.29 \\
\hline & Heavy oil (kg) & 7.43 & 271.29 & 5.21 & 276.50 & 23.86 & 4.56 & 28.42 \\
\hline & Natural gas $\left(\mathrm{m}^{3}\right)$ & 9.16 & 271.29 & 5.21 & 276.50 & 17.62 & 4.56 & 22.18 \\
\hline \multirow[t]{3}{*}{ Limestone + bitumen } & Diesel (kg) & 6.51 & 225.45 & 5.21 & 230.66 & 17.04 & 4.56 & 21.60 \\
\hline & Heavy oil (kg) & 6.42 & 225.45 & 5.21 & 230.66 & 20.61 & 4.56 & 25.18 \\
\hline & Natural gas $\left(\mathrm{m}^{3}\right)$ & 7.91 & 225.45 & 5.21 & 230.66 & 15.22 & 4.56 & 19.78 \\
\hline Ceremic+PU & & & & 0.58 & 0.58 & & 0.50 & 0.50 \\
\hline
\end{tabular}


friendliness, asphalt pavement has gained popularity in long tunnels due to its low noise and dust emissions, easy maintenance and good comfort. However, conventional tunnel asphalt pavements also have safety and environmental shortcomings [91-93]. The innovative polyurethane-based paving material $[39,51]$ has been developed to be a substitute.

In contrast to the conventional tunnel pavement materials, the innovative polyurethane-based ultra-thin friction course (UTFC) has significant improvements in the mechanical and functional properties as well as the environmental performance $[39,51]$. The excellent mechanical properties were verified in the Marshall stability and splitting strength, lised in Tables 3 and 4 [39], repectively. As lised, although the PUM exhibits relatively poor water stability, its residual mechanical properties are still much higher than that of the asphalt mixture. The excellent functional properties mainly include the wear resistance, noise absorption performance and flame resistance, showin in Fig. 5 [39], Fig. 6 [51] and Table 5 [39], respectively. The excellent environmental performance showed in the lower global warming potential (GWP) and energy consumption, lised in Table 6 [39]. Therefore, the above two PU/UTFCs will resolve significant problems in asphalt pavement in the tunnel and possess a broader application prospect.

\section{Polyurethane bridge deck paving material}

The polyurethane mixture (PUM) was gradually designed as the bridge deck paving material [52-54]. In contrast to the conventional asphalt bridge deck paving material, the polyurethane bridge deck paving material showed excellent dynamic stability, toughness, water stability, low-temperature sensitivity, fatigue performance as well as the full waterproof function, which fully meets the requirements of bridge deck paving material [53, 54], listed in Table 7. In addition, compared to the SBS modified asphalt mixture, the polyurethane bridge deck paving material was verified to have an excellent long-term service under the photothermal coupling aging and thermooxidative aging [52]. However, polyurethane bridge deck paving material is in the development stage and has not been applied successfully.

\section{Other applications}

The PU resin is often used as the sealant for the expansion joints or maintenance of bridge decks [101] and concrete pavements [70]. In the process of using, the PU sealant is inevitably subjected to the effects of vehicle loads, ambient temperature, moisture or water, creep, etc., [102]. Moreover, the failure of sealant in the expansion joints will lead to further damage to concrete pavement [102]. Fortunately, the PU sealant [103, 104 ] is well suited to the above task due to its excellent

Table 3 The Marshall stability of the polyurethane mixture used for tunnel pavement, compared to the conventional asphalt mixture

\begin{tabular}{|c|c|c|c|c|c|c|}
\hline \multirow[t]{2}{*}{ Type of mixture } & \multirow[t]{2}{*}{ Gradation type } & \multicolumn{3}{|l|}{ Marshall stability } & \multirow{2}{*}{$\begin{array}{l}\text { Technical } \\
\text { requirements } \\
\text { (Residual value, \%) }\end{array}$} & \multirow[t]{2}{*}{ Test method } \\
\hline & & $\begin{array}{l}\text { Before water } \\
\text { immersion (kN) }\end{array}$ & $\begin{array}{l}\text { After water } \\
\text { immersion } \\
(\mathrm{kN})\end{array}$ & $\begin{array}{l}\text { Residual } \\
\text { value (\%) }\end{array}$ & & \\
\hline \multirow[t]{2}{*}{ Polyurethane mixture } & $A C-10[39]$ & 110.2 & 86.8 & 78.8 & - & T 0709 in JTG E20-2011, China \\
\hline & OGFC-10 [39] & 80.3 & 66.8 & 83.2 & & \\
\hline \multirow[t]{3}{*}{ Asphalt mixture } & SMA-16 [94] & 11.8 & 10.5 & 89.0 & $\geq 75.0$ & \\
\hline & $A C-16 \mid[95]$ & 8.5 & 7.3 & 85.9 & & \\
\hline & $A C-13 \mid[95]$ & 8.4 & 7.5 & 89.3 & & \\
\hline
\end{tabular}

Table 4 The splitting strength of the polyurethane mixture used for tunnel pavement, compared to the conventional asphalt mixture

\begin{tabular}{|c|c|c|c|c|c|c|}
\hline \multirow[t]{2}{*}{ Type of mixture } & \multirow[t]{2}{*}{ Gradation type } & \multicolumn{3}{|l|}{ Splitting stregth } & \multirow{2}{*}{$\begin{array}{l}\text { Technical } \\
\text { requirements } \\
\text { (Residual value, \%) }\end{array}$} & \multirow[t]{2}{*}{ Test method } \\
\hline & & $\begin{array}{l}\text { Before the first } \\
\text { freeze-thaw cycle } \\
\text { (MPa) }\end{array}$ & $\begin{array}{l}\text { After the first } \\
\text { freeze-thaw cycle } \\
\text { (MPa) }\end{array}$ & $\begin{array}{l}\text { Residual } \\
\text { value (\%) }\end{array}$ & & \\
\hline \multirow[t]{2}{*}{ Polyurethane mixture } & AC-10 [39] & 5.8 & 2.5 & 43.1 & \multirow[t]{2}{*}{-} & \multirow{4}{*}{$\begin{array}{l}\text { T } 0729 \text { in JTG E20-2011 } \\
\text { China }\end{array}$} \\
\hline & OGFC-10 [39] & 3.7 & 2.0 & 54.1 & & \\
\hline \multirow{2}{*}{ Asphalt mixture } & AC-16I [95] & 0.825 & 0.670 & 81.2 & \multirow[t]{2}{*}{$\geq 70.0$} & \\
\hline & AC-13I [95] & 0.825 & 0.587 & 71.2 & & \\
\hline
\end{tabular}




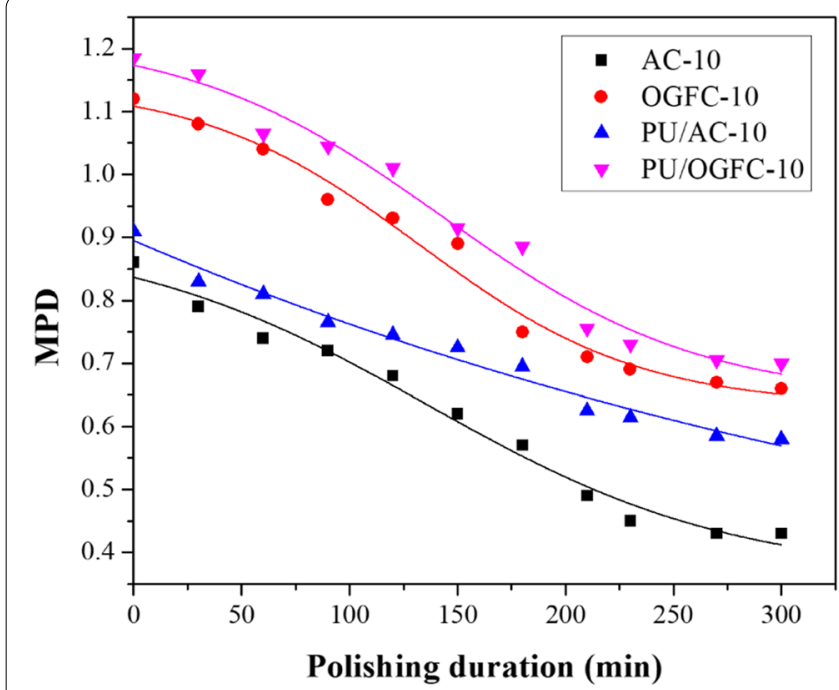

(a)

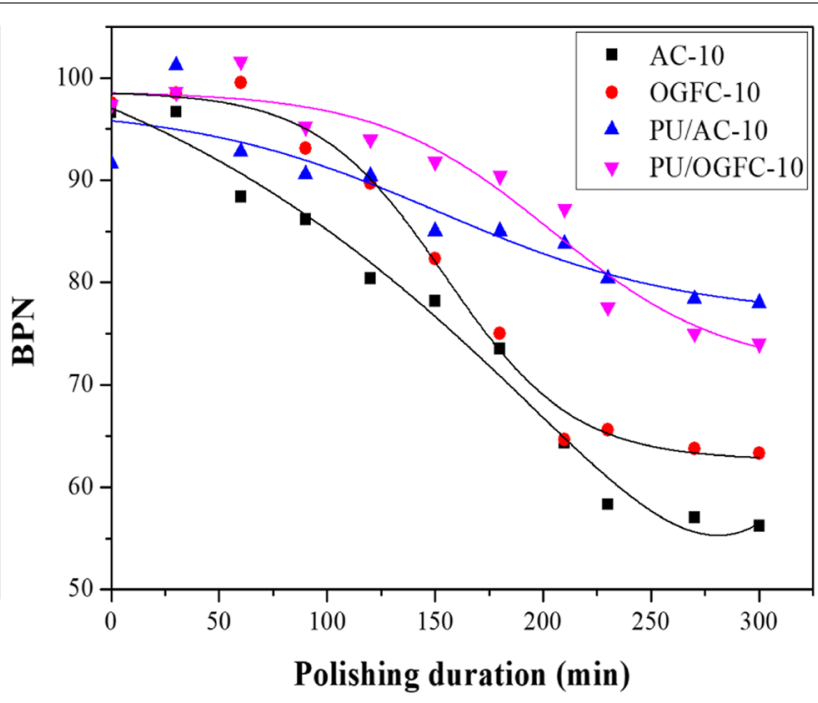

(b)

Fig. 5 The comparison of skid resistance between the polyurethane mixture and asphalt mixture [39]: a The mean profile depth (MPD) test values; b The British pendulum number (BPN) test values

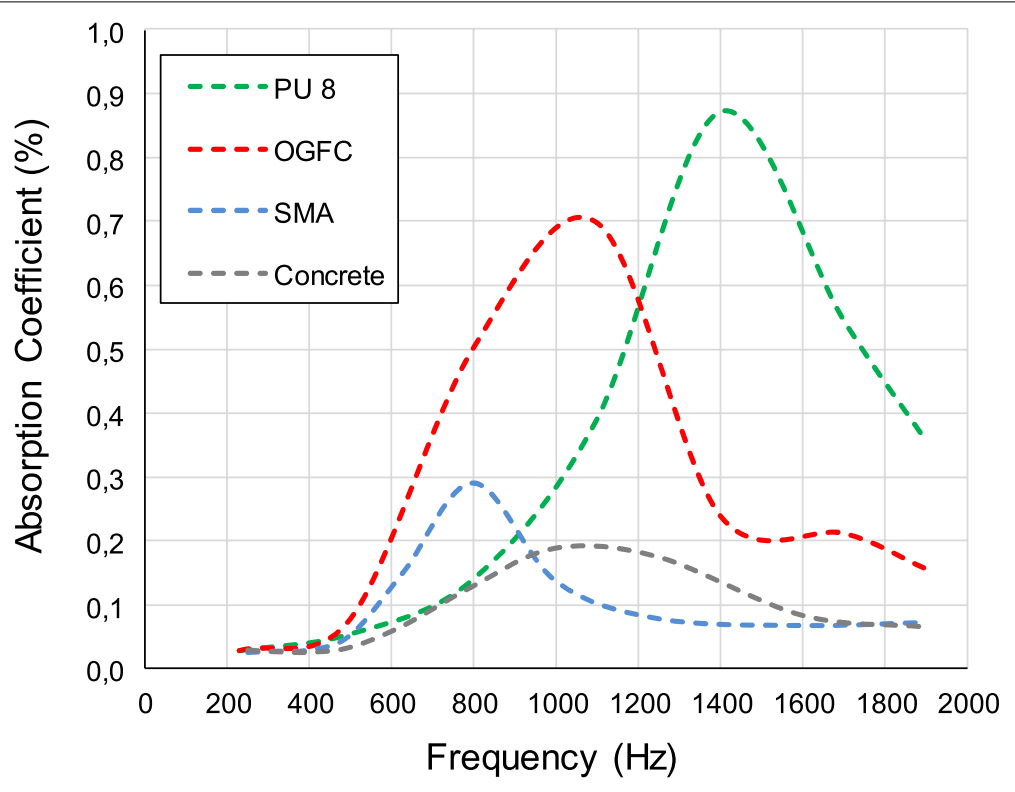

Fig. 6 The comparison of acoustic absorption coefficient between the polyurethane mixture and asphalt mixture [51]

toughness or even good shape memory characteristic [70], strong adhesive, good strength, abrasion resistance, fatigue resistance, corrosion resistance, UV aging resistance, etc. In addition, in the early stage, the polyurethane was mainly used as the light-load pavement materials $[45,48]$, such as park roads, sidewalks, sports grounds, runways, etc.

\section{Conclusions and outlook}

The above studies have provided a lot of experimental and theoretical basis for material genome design of polyurethane pavement materials. The results have shown that the polyurethane mixture has excellent mechanical properties, corrosion resistance, ultraviolet aging resistance and wear resistance, as well as good anti-blocking, 
Table 5 The comparison of ignition time (TTI) between the polyurethane mixture and asphalt mixture

\begin{tabular}{lll}
\hline Type of mixture & Gradation type & TTI (s) \\
\hline Polyurethane mixture & AC-10 [39] & 313 \\
& OGFC-10 [39] & 299 \\
& PU 8 [51] & 142 \\
Asphalt mixture & AC-10 [39] & 34 \\
& OGFC-10 [39] & 35 \\
OGFC [51] & 90 \\
& SMA [51] & 108 \\
\hline
\end{tabular}

Table 6 The comparison of environmental impact analysis between the polyurethane mixture and asphalt mixture [39]

\begin{tabular}{llll}
\hline Type of mixture & Gradation type & $\begin{array}{l}\text { Global warming } \\
\text { potential (GWP) }\end{array}$ & $\begin{array}{l}\text { Energy } \\
\text { consumption } \\
\text { (MJ) }\end{array}$ \\
\hline $\begin{array}{l}\text { Polyurethane } \\
\text { mixture }\end{array}$ & OGFC & 72.7 & 177.8 \\
Asphalt mixture & OGFC & 110.1 & 640.3 \\
\hline
\end{tabular}

anti-peeling and noise reduction properties. However, due to the lack of supporting construction technology and the lack of corresponding specifications, the polyurethane mixture is still in the initial research and development stage. Some studies have carried out the verification of the test track, but the application of the actual project is still to be improved. In addition, polyurethane mixture should have a good long-term service performance, but the current study does not for polyurethane comprehensive evaluation of the durability of the concrete, such as have been found under the action of freeze-thaw cycle polyurethane road gravel mixture is the evolution of the reports, also did not find a variety of service environments polyurethane concrete splitting properties, permeability resistance, uniaxial compression performance, Marshall stability, bending properties, shear strength and resistance to chloride-ion permeability, etc. Therefore, the future research direction of polyurethane mixture mainly including pavement material preparation technology, long-term service performance evaluation and control, construction technology and standard, its main application in the permeable pavement (such as sponge city), the surfacing layer, even can also be applied in polyurethane mixture as a new carrier of intelligent road.

In general, facing the diversity and unpredictability of future climate and traffic load, the gene-editable characteristics of PU materials have laid a solid foundation for the on-demand design of paving materials in the future. It can effectively combine the advantages of both asphalt and cement pavement while avoiding the disadvantages of traditional materials. In addition, the construction process of PU materials is more environmental-friendly, which in line with the future Carbon neutral policy.

Considering the gene-editable nature of polyurethane, further research on the polyurethane-based pavement is believed to implement its on-demand design based on the material genome design theory. For this purpose, the raw material gene database, material terminal performance database and their structure-activity relationship will be established by a certain amount of experimental research and theoretical calculations for high throughput. In addition, the verification of demonstration engineering applications is also essential.

Table 7 The comparison of the road performance between the polyurethane- and asphalt-based bridge deck pavement materials

\begin{tabular}{|c|c|c|c|c|}
\hline Technical index & Type of mixture & Test result & $\begin{array}{l}\text { Technical } \\
\text { requirements }\end{array}$ & Test method \\
\hline Dynamic stability $\left(70^{\circ} \mathrm{C}, 0.7 \mathrm{MPa}\right) /($ passes $/ \mathrm{mm})$ & Polyurethane mixture [53] & 69750 & $\geq 6000$ & T 0719 in JTG E20-2011, China \\
\hline \multirow{2}{*}{ Dynamic stability $\left(60^{\circ} \mathrm{C}, 0.7 \mathrm{MPa}\right) /($ passes $/ \mathrm{mm})$} & Base asphalt mixture [96] & 1691 & $\geq 1000$ & \\
\hline & SBS modified asphalt mixture [96] & 6503 & $\geq 2800$ & \\
\hline \multirow[t]{3}{*}{ Residual splitting strength after freeze-thawing / \% } & Polyurethane mixture [53] & 80 & - & T 0729 in JTG E20-2011, China \\
\hline & Base asphalt mixture [96] & 77.6 & $\geq 70$ & \\
\hline & SBS modified asphalt mixture [96] & 90.0 & $\geq 75$ & \\
\hline Fatigue life $\left(15^{\circ} \mathrm{C}, 1200 \mu \varepsilon\right) / 10^{4}$ & Polyurethane mixture [53] & 168 & - & T 0739 in JTG E20-2011, China \\
\hline Fatigue life $\left(15^{\circ} \mathrm{C}, 0.6\right.$ stress ratio) $/ 10^{4}$ & Asphalt mixture [97] & 2.07 & - & \\
\hline Fatigue life $\left(20^{\circ} \mathrm{C}, 1000 \mu \varepsilon\right) / 10^{4}$ & Asphalt mixture [98] & 0.2856 & - & \\
\hline \multirow[t]{2}{*}{ Low-temperature flexural tensile strain $\left(-10^{\circ} \mathrm{C}\right) / \mu \varepsilon$} & Polyurethane mixture [53] & 48762 & - & T 0728 in JTG E20-2011, China \\
\hline & Asphalt mixture [99] & 2322 & $\geq 2000$ & \\
\hline \multirow[t]{2}{*}{ Water permeability coefficient $/\left(\mathrm{ml} \cdot \mathrm{min}^{-1}\right)$} & Polyurethane mixture [53] & No seepage & $\leq 200$ & T 0730 in JTG E20-2011, China \\
\hline & Asphalt mixture [100] & No seepage & $\leq 200$ & \\
\hline
\end{tabular}




\begin{abstract}
Abbreviations
PU: Polyurethane; GHG: Green House Gas; SBS: Styrene-Butadiene-Styrene; PE: Polyethylene; EVA: Ethylene-vinyl acetate copolymer; SBR: Styrene-butadiene rubber; PET: Polyester; CR: Crumb rubber; VOCs: Volatile organic compounds; CRCP: Continuous reinforced concrete pavement; MGI: Materials Genome Initiative; UV: Ultraviolet; PUMs: Polyurethane mixtures; PUM: Polyurethane mixture; FEM: Finite Element Method; DFT: Density Functional Theory; PC: Polymer concrete; PTO: Polyurethane overlay; PA: Porous asphalt; PPM: Polyurethane pavement material; PUPM: Polyurethane porous mixture; PERS: Poroelastic Road Surface; PCRP: PU-bound Ceramics Recycled (Porous) Pavement; UTFC: Ultra-thin friction course; GWP: Global warming potential; PU/UTFCs: Polyurethane-based ultra-thin friction course; AC: Asphalt concrete; OGFC: Open graded friction course; SMA: Stone matrix asphalt; MPD: Mean profile depth; BPN: British pendulum number; TTl: Ignition time.
\end{abstract}

\section{Acknowledgements}

Since the main works of this study were finished in Harbin Institute of Technology (HIT), the authors gratefully acknowledge the support of HIT and international collaborators.

\section{Authors' contributions}

Bin Hong: Conceptualization, Methodology, Data curation, Manuscript writing; Guoyang Lu: Conceptualization, Methodology, Data curation, Manuscript writing; Tianshuai Li: Data curation, Manuscript writing; Jiao Lin: Data curation, Manuscript writing; Dawei Wang: Conceptualization, Methodology, WritingReviewing and Editing; Dong Liang: Writing- Reviewing and Editing; Markus Oeser:Writing- Reviewing and Editing. All authors reviewed the results and approved the final version of the manuscript.

\section{Funding}

This work was financially supported by National Key Research and Development Program of China (Grant No. 2018YFB1600100), German Research Foundation (DFG) under Grant No. OE 514/15-1 (459436571), National Natural Science Foundation of China (Grant No. 51908165), Natural Science Foundation of Heilongjiang Province (Grant No. JJ2020ZD0015), China Postdoctoral Science Foundation funded project (Grant No. BX20180088), and Heilongjiang Postdoctoral Fund (Grant No. LBH-Z18083).

\section{Availability of data and materials}

All data, models, materials and code generated or used during the study appear in the submitted article.

\section{Declarations}

\section{Ethics approval and consent to participate}

Not applicable.

\section{Consent for publication}

Not applicable.

\section{Competing interests}

The authors declare that they have no competing interests.

\begin{abstract}
Author details
${ }^{1}$ School of Transportation Science and Engineering, Harbin Institute of Technology, 73 Huanghe Road, Nangang District, Harbin 150090, P.R. China. ${ }^{2}$ Department of Civil and Environmental Engineering, The Hong Kong Polytechnic University, 11 Yuk Choi Road, Hung Hom, Kowloon, Hong Kong, P.R. China. ${ }^{3}$ Institute of Highway Engineering, RWTH Aachen University, Mies-van-der-Rohe-Straße 1, 52074 Aachen, Germany. ${ }^{4}$ BASF Polyurethane Specialties (China) Company Ltd., 333 Jiang Xin Sha Road, Pu Dong New District, Shanghai 200137, P.R. China.
\end{abstract}

Received: 3 August 2021 Accepted: 31 August 2021 Published online: 19 October 2021

\section{References}

1. Huang XM (2019) Road subgrade and pavement engineering, 6th edn. China Communications Press Co., Ltd., Beijing
2. Tan YQ (2007) Bitumen and bituminous mixtures. Harbin Institute of Technology Press, Harbin

3. Hu J, Yu X (2013) Experimental study of sustainable asphalt binder influence of thermochromic materials. Transp Res Rec 2372:108-115

4. Plati C (2019) Sustainability factors in pavement materials, design, and preservation strategies: A literature review. Constr Build Mater 211:539-555

5. Hunter RN (2000) Asphalts in road construction. Thomas Telford Publishing, Thomas Telford

6. Al-Qadi IL, Son S, Carpenter SH (2013) Development of an economical, thin, quiet, long-lasting, high friction surface layer, Volume 1: mix design and lab performance testing (No. FHWA-ICT-13-001). Illinois Department of Transportation, Bureau of Materials and Physical Research, Springfield

7. LiT (2018) Influencing parameters on tire-pavement interaction noise: review, experiments and design considerations. Designs 2(4):38

8. Swieczko-Zurek B, Jaskula P, Ejsmont JA, Kedzierska A, Czajkowski P (2017) Rolling resistance and tyre/road noise on rubberised asphalt pavement in Poland. Road Mater Pavement 18(1):151-167

9. Wen G, Zhang Y, Zhang YX, Sun K, Fan YZ (2002) Rheological characterization of storage-stable SBS-modified asphalts. Polym Test 21(3):295-302

10. Khodaii A, Mehrara A (2009) Evaluation of permanent deformation of unmodified and SBS modified asphalt mixtures using dynamic creep test. Constr Build Mater 23(7):2586-2592

11. Liang $M$, Xin X, Fan WY, Luo H, Wang XB, Xing BD (2015) Investigation of the rheological properties and storage stability of CR/SBS modified asphalt. Constr Build Mater 74:235-240

12. Zhao XY, Wang SF, Wang Q, Yao HR (2016) Rheological and structural evolution of SBS modified asphalts under natural weathering. Fuel 184:242-247

13. Mull MA, Stuart K, Yehia A (2002) Fracture resistance characterization of chemically modified crumb rubber asphalt pavement. J Mater Sci 37(3):557-566

14. Rochlani M, Leischner S, Wareham D, Caro S, Falla GC, Wellner F (2020) Investigating the performance-related properties of crumb rubber modified bitumen using rheology-based tests. Int J Pavement Eng AHEAD-OF-PRINT:1-11. https://doi.org/10.1080/10298436.2020.17768 68

15. U.S. EPA (2020) Inventory of U.S. Greenhouse gas emissions and sinks:1990-2018. United States Environmental Protection Agency, Washington

16. Chen XD, Wang H (2018) Life cycle assessment of asphalt pavement recycling for greenhouse gas emission with temporal aspect. J Clean Prod 187:148-157

17. Copeland A (2011) Reclaimed asphalt pavement in asphalt mixtures: State of the practice (No. FHWA-HRT-11-021). Federal Highway Administration, Richmond

18. Cui P, Schito G, Cui QB (2020) VOC emissions from asphalt pavement and health risks to construction workers. J Clean Prod 244:118757. https://doi.org/10.1016/j.jclepro.2019.118757

19. Peralta J, Raouf MA, Tang S, Williams RC (2012) Bio-renewable asphalt modifiers and asphalt substitutes. In: Sustainable bioenergy and bioproducts. Springer, London

20. Lu GY, Torzs T, Liu PF, Zhang ZY, Wang DW, Oeser M, Grabe J (2020) Dynamic response of fully permeable pavements: development of pore pressures under different modes of loading. J Mater Civ Eng 32(7):04020160. https://doi.org/10.1061/(ASCE)MT.1943-5533.0003217

21. Yu JY, Cong PL, Wu SP (2009) Laboratory investigation of the properties of asphalt modified with epoxy resin. J Appl Polym Sci 113(6):3557-3563

22. Lu GY, Liu PF, Wang YH, Fassbender S, Wang DW, Oeser M (2019) Development of a sustainable pervious pavement material using recycled ceramic aggregate and bio-based polyurethane binder. J Clean Prod 220:1052-1060

23. Lu Q, Bors J (2015) Alternate uses of epoxy asphalt on bridge decks and roadways. Constr Build Mater 78:18-25

24. Graeff AG, Pilakoutas K, Neocleous K, Peres MVNN (2012) Fatigue resistance and cracking mechanism of concrete pavements reinforced with recycled steel fibres recovered from post-consumer tyres. Eng Struct 45:385-395 
25. West G (1996) Alkali-aggregate reaction in concrete roads and bridges. Thomas Telford Publications, London

26. Shah DS, Pitroda J, Bhavsar JJ (2013) Pervious concrete: new era for rural road pavement. Int J Eng Trends Technol 4(8):3495-3499

27. Wang J (2012) Analysis the Control techniques of reflection crack on asphalt overlay of old cement concrete pavement. Appl Mech Mater 204-208:1945-1948

28. Saxena P, Khazanovich $L$ (2012) Determination of critical bending stresses in portland cement concrete layer with asphalt overlay. Transp Res Rec 2306:36-44

29. Stryk J, Matula R, Pospisil K (2013) Possibilities of ground penetrating radar usage within acceptance tests of rigid pavements. J Appl Geophys 97:11-26

30. Yang GT, Bradford MA (2018) Thermal-induced upheaval buckling of concrete pavements incorporating the effects of temperature gradient. Eng Struct 164:316-324

31. Sarkar A, Norouzi R (2020) Evaluating Curling Stress of Continuous Reinforced Concrete Pavement. ACI Struct J 117(1):53-62

32. Talaei A, Pier D, lyer AV, Ahiduzzaman M, Kumar A (2019) Assessment of long-term energy efficiency improvement and greenhouse gas emissions mitigation options for the cement industry. Energy 170:1051-1066

33. Barcelo L, Kline J, Walenta G, Gartner E (2014) Cement and carbon emissions. Mater Struct 47(6):1055-1065

34. Demailly D, Quirion P (2006) CO2 abatement, competitiveness and leakage in the European cement industry under the EU ETS: grandfathering versus output-based allocation. Clim Pol 6(1):93-113

35. Häkkinen T, Mäkelä K (1996) Environmental adaption of concrete: Environmental impact of concrete and asphalt pavements. VTT Technical Research Centre of Finland, Espoo

36. Drosback M (2014) Materials genome initiative: Advances and initiatives. JOM 66(3):334-335

37. Chen LQ (2015) The materials genome initiative and advanced materials. Engineering 1(2):169-169

38. Hou Y, Li Q, Zhang C, Lu G, Ye Z, Chen Y, Wang L, Cao D (2020) The state-of-the-art review on applications of intrusive sensing, image processing techniques, and machine learning methods in pavement monitoring and analysis. Engineering 7(6):845-856. https://doi.org/ 10.1016/j.eng.2020.07.030

39. Hong B, Lu G, Gao J, Dong S, Wang D (2021) Green tunnel pavement: Polyurethane ultra-thin friction course and its performance characterization. J Clean Prod 289:125131. https://doi.org/10.1016/j.jclepro. 2020.125131

40. Hong B, Lu G, Gao J, Wang D (2021) Evaluation of polyurethane dense graded concrete prepared using the vacuum assisted resin transfer molding technology. Constr Build Mater 269:121340. https:// doi.org/10.1016/j.conbuildmat.2020.121340

41. Hong B, Xian G, Li H (2018) Effects of water or alkali solution immersion on the water uptake and physicomechanical properties of polyurethane. Polym Eng Sci 58(12):2276-2287

42. Hong B, Lu GY, Gao JL, Wang CH, Wang DW (2020) Study on the antiultraviolet aging performance of the polyurethane binder used in road, China. J Highw Transp 33(10):240-253

43. Sandberg U (1999) Low noise road surfaces-a state-of-the-art review. J Acoust Soc Jpn 20(1):1-17

44. Hepburn C (1992) Polyurethane elastomers. Springer, Netherlands

45. Wang HM, Li RK, Wang X, Ling TQ, Zhou G (2014) Strength and road performance for porous polyurethane mixture, China. J Highw Transp 27(10):24-31

46. Renken L, Oeser M, Milatz M, Grabe J (2016) Measurement of hydraulic properties of unsaturated permeable polyurethane bound asphalt materials, Unsaturated soil mechanics-from theory to practice, pp 407-412

47. Lu GY, Renken L, Li TS, Wang DW, Li H, Oeser M (2019) Experimental study on the polyurethane-bound pervious mixtures in the application of permeable pavements. Constr Build Mater 202:838-850

48. Lu G, Wang Y, Li H, Wang D, Oeser M (2019) The environmental impact evaluation on the application of permeable pavement based on life cycle analysis. Int J Transp Sci Technol 8(4):351-357

49. Lu GY, Wang HP, Zhang YQ, Liu PF, Wang DW, Oeser M, Grabe J (2021) The hydro-mechanical interaction in novel polyurethane-bound pervious pavement by considering the saturation states in unbound granular base course. Int J Pavement Eng:1-14. https://doi.org/10.1080/ 10298436.2021.1915490

50. Lu GY, Wang HP, Torzs T, Liu PF, Zhang YQ, Wang DW, Oeser M, Grabe J (2020) In-situ and numerical investigation on the dynamic response of unbounded granular material in permeable pavement. Transp Geotech 25:100396. https://doi.org/10.1016/j.trgeo.2020.100396

51. Leng C, Lu GY, Gao JL, Liu PF, Xie XG, Wang DW (2019) Sustainable green pavement using bio-based polyurethane binder in tunnel. Materials 12(12):1990. https://doi.org/10.3390/ma12121990

52. Xu S, Xu M, Zhang Y, Guo Y, Peng G, Xu Y (2020) An indoor laboratory simulation and evaluation on the aging resistance of polyether polyurethane concrete for bridge deck pavement. Front Mater 7:237. https:// doi.org/10.3389/fmats.2020.00237

53. Wang R, Hu Z, Shi J, Li S, Xu S, Duan W (2018) Development and pavement performance evaluation of paving materials with high molecular polymer. Road Mach Constr Mech 35(10):39-42

54. Li S, Hu C, Hu L, Li J, Duan W, Xu S (2018) Technical progress of deck paving materials with high molecular polymer for concrete steel bridge. Road Mach Constr Mech 35(10):35-38

55. Huang H, Pang H, Huang JH, Zhao HW, Liao B (2020) Synthesis and characterization of ground glass fiber reinforced polyurethane-based polymer concrete as a cementitious runway repair material. Constr Build Mater 242:117221. https://doi.org/10.1016/j.conbuiltdmat.2019. 117221

56. Sharmin E, Zafar F (2012) Polyurethane: An introduction. In: Polyurethane. InTech, Croatla. http://dx.doi.org/10.5772/51663

57. Chen J, Yin XJ, Wang H, Ding YM (2018) Evaluation of durability and functional performance of porous polyurethane mixture in porous pavement. J Clean Prod 188:12-19

58. Hong B, Xian G (2018) Ageing of a thermosetting polyurethane and its pultruded carbon fiber plates subjected to seawater immersion. Constr Build Mater 165:514-522

59. Hong B, Xian G, Wang Z (2017) Durability study of pultruded carbon fiber reinforced polymer plates subjected to water immersion. Adv Struct Eng 21(4):571-579

60. Xing C, Tan YQ, Zhang K, Shan LY, Xu HN (2020) Review and prospect of genetic characteristics of asphalt mixture based on material genome method, China. J Highw Transp 33(10):76-90

61. Wang H, Liu HX, Zhuang CH (2012) Study on the polyurethane concrete for the rapid repairment of highway pavement. Appl Mech Mater 193-194:762-769

62. Fowler DW (1999) Polymers in concrete: a vision for the 21 st century. Cement Concrete Comp 21(5-6):449-452

63. Czarnecki L, Garbacz A, Kurach J (2001) On the characterization of polymer concrete fracture surface. Cement Concrete Comp 23(4-5):399-409

64. Czarnecki L (1985) The status of polymer concrete. Concr Int 7(7):47-53

65. Mounanga P, Gbongbon W, Poullain P, Turcry P (2008) Proportioning and characterization of lightweight concrete mixtures made with rigid polyurethane foam wastes. Cement Concrete Comp 30(9):806-814

66. Fernández-Gómez WD, Quintana HR, Lizcano FR (2013) A review of asphalt and asphalt mixture aging: Una revisión. Ing Investig 33(1):5-12

67. Hicks RG (1991) Moisture damage in asphalt concrete. Transportation Research Board, Washington

68. Han JC (2017) Manufacturing and study on properties of polyurethane (PU) modified bitumen emulsions. Chang'an University, Xi'an

69. Sheng XH, Wang M, Xu T, Chen J (2018) Preparation, properties and modification mechanism of polyurethane modified emulsified asphalt. Constr Build Mater 189:375-383

70. Shen DY, Shi S, Xu T, Huang XM, Liao GY, Chen J (2018) Development of shape memory polyurethane based sealant for concrete pavement. Constr Build Mater 174:474-483

71. Gao PW, Lu XL, Li XY, Geng F, Le JX, Chen WF (2007) Novel repair materials and techniques for airport pavement, international conference on transportation engineering. American Society of Civil Engineers, Chengdu

72. Molenaar AAA, Meerkerk A, Miradi M, van der Steen T (2006) Performance of porous asphalt concrete. J Assoc Asphalt Paving Technol 75:1053-1094 
73. Mo LT, Huurman M, Wu SP, Molenaar AAA (2007) Investigation into stress states in porous asphalt concrete on the basis of FE-modelling. Finite Elem Anal Des 43(4):333-343

74. Elvik R, Greibe P (2005) Road safety effects of porous asphalt: a systematic review of evaluation studies. Accid Anal Prev 37(3):515-522

75. Zhang HJ, Li H, Zhang Y, Wang DW, Harvey J, Wang HB (2018) Performance enhancement of porous asphalt pavement using red mud as alternative filler. Constr Build Mater 160:707-713

76. Mo LT, Huurman M, Wu SP, Molenaar AAA (2011) Bitumen-stone adhesive zone damage model for the meso-mechanical mixture design of ravelling resistant porous asphalt concrete. Int J Fatigue 33(11):1490-1503

77. Mo LT, Huurman M, Woldekidan MF, Wu SP, Molenaar AAA (2010) Investigation into material optimization and development for improved ravelling resistant porous asphalt concrete. Mater Des 31(7):3194-3206

78. Mo LT (2010) Damage development in the adhesive zone and mortar of porous asphalt concrete. Delft University of Technology, Delft

79. Huurman M, Mo LT, Woldekidan MF (2010) Porous asphalt ravelling in cold weather conditions. Int J Pavement Res Technol 3(3):110-118

80. Mo LT, Huurman M, Wu SP, Molenaar AAA (2009) Ravelling investigation of porous asphalt concrete based on fatigue characteristics of bitumenstone adhesion and mortar. Mater Des 30(1):170-179

81. Mo LT, Huurman M, Wu SP, Molenaar AAA (2008) 2D and 3D meso-scale finite element models for ravelling analysis of porous asphalt concrete. Finite Elem Anal Des 44(4):186-196

82. Hagos ET (2008) The effect of aging on binder proporties of porous asphalt concrete (Doctoral thesis). Delft University of Technology, Delft

83. Huurman M, Mo L, Woldekidan MF, Khedoe RN, Moraal J (2009) Overview of the LOT meso mechanical research into porous asphalt raveling. Adv Test Character Bituminous Mater 1-2:507-518

84. Renken L, Oeser M (2015) Entwicklung von Deckschichtmaterialien fuer versickerungsfaehige Verkehrsflaechenbefestigungen auf Basis alternativer Bindemittel - Teil 1: Festigkeit, Permeabilitaet, Kornverlust / Development of materials for permeable pavements based on polyurethane. Straße Und Autobahn 66(9):601-608

85. Renken L, Oeser M (2014) Innovative Baustoffkonzepte-Anwendungspotenziale und Charakterisierung von synthetischen Strassenbefestigungen, Aachener Mitteilungen Strassenwesen. erd-und tunnelbau (62):101-112. https://trid.trb.org/view/1349808

86. Cong L, Wang TJ, Tan L, Yuan JJ, Shi JC (2018) Laboratory evaluation on performance of porous polyurethane mixtures and OGFC. Constr Build Mater 169:436-442

87. Ma X, Li Q, Cui Y-C, Ni A-Q (2016) Performance of porous asphalt mixture with various additives. Int J Pavement Eng 19(4):355-361

88. Agar-Ozbek AS, Weerheijm J, Schlangen E, Breugel KV (2013) Investigating porous concrete with improved strength: Testing at different scales. Constr Build Mater 41:480-490

89. Wang DW, Schacht A, Leng Z, Leng C, Kollmann J, Oeser M (2017) Effects of material composition on mechanical and acoustic performance of poroelastic road surface (PERS). Constr Build Mater 135:352-360

90. Wang DW, Liu PF, Leng Z, Leng C, Lu GY, Buch M, Oeser M (2017) Suitability of PoroElastic Road Surface (PERS) for urban roads in cold regions: Mechanical and functional performance assessment. J Clean Prod 165:1340-1350

91. Sheng Y, Wu Y, Yan Y, Jia H, Qiao Y, Underwood BS, Niu D, Kim YR (2020) Development of environmentally friendly flame retardant to achieve low flammability for asphalt binder used in tunnel pavements. J Clean Prod 257:120487. https://doi.org/10.1016/j.jclepro.2020.120487

92. Wu X, Liu H, Zhang L, Skibniewski MJ, Deng Q, Teng J (2015) A dynamic Bayesian network based approach to safety decision support in tunnel construction. Reliab Eng Syst Saf 134:157-168

93. Koch C, Georgieva K, Kasireddy V, Akinci B, Fieguth P (2015) A review on computer vision based defect detection and condition assessment of concrete and asphalt civil infrastructure. Adv Eng Inform 29(2):196-210

94. Cong P, Yu J, Wu S, Luo X (2008) Laboratory investigation of the properties of asphalt and its mixtures modified with flame retardant. Constr Build Mater 22(6):1037-1042

95. Cai Y, Zheng Y (2011) Experiment study of water stability of fiber-reinforced asphalt mixture. Adv Mater Res 243-249:710-716

96. Zou X, Sha A, Jiang W, Huang X (2015) Modification mechanism of high modulus asphalt binders and mixtures performance evaluation. Constr Build Mater 90:53-58

97. Ma T, Zhang Y, Zhang D, Yan J, Ye Q (2016) Influences by air voids on fatigue life of asphalt mixture based on discrete element method. Constr Build Mater 126:785-799

98. Mannan UA, Islam MR, Tarefder RA (2015) Effects of recycled asphalt pavements on the fatigue life of asphalt under different strain levels and loading frequencies. Int J Fatigue 78:72-80

99. Liu Q, Yu W, Wu S, Schlangen E, Pan P (2017) A comparative study of the induction healing behaviors of hot and warm mix asphalt. Constr Build Mater 144:663-670

100. Ai C, Rahman A, Wang F, Yang E, Qiu Y (2017) Experimental study of a new modified waterproof asphalt concrete and its performance on bridge deck. Road Mater Pavement 18(sup3):270-280

101. Li G, Xu T (2011) A shape memory polymer based self-healing syntactic foam sealant for expansion joint, Structures Congress 2011. American Society of Civil Engineers, Las Vegas

102. Xie YJ, Mo LT, Su DL, Woldekidan MF, Wu SP (2013) Investigation into fundamental properties of bituminous plug expansion joint filling mixtures containing rubber granules. Constr Build Mater 47:984-989

103. Xu L, Shang P, Xu XW, Herrick AM, Sgro A, Shou CQ (2011) Studies on synthesis and properties of novel polyurethane pavement joint sealant modified with polydimethysiloxane. Mater Res Innov 15(2):150-155

104. Carbonell-Blasco P, Martin-Martinez JM, Antoniac IV (2013) Synthesis and characterization of polyurethane sealants containing rosin intended for sealing defect in annulus for disc regeneration. Int J Adhes Adhes 42:11-20

\section{Publisher's Note}

Springer Nature remains neutral with regard to jurisdictional claims in published maps and institutional affiliations.

\section{Submit your manuscript to a SpringerOpen ${ }^{\circ}$ journal and benefit from:}

- Convenient online submission

- Rigorous peer review

- Open access: articles freely available online

- High visibility within the field

- Retaining the copyright to your article

Submit your next manuscript at springeropen.com 